\title{
Community Property and the Federal Income $\mathrm{Tax}$
}

\author{
PART II \\ V. "BENEFICIAL OWNERSHIP" AS TEST OF \\ INCOME-TAX LIABILITY
}

If, in subsequent cases, the Supreme Court adheres to the position taken by it in United States v. Robbins, ${ }^{71}$ it seems that it can do so only upon the theory that beneficial ownership as distinguished from legal ownership is in and of itself a proper test of income-tax liability.

Legal ownership of property is a rather refined conception. The layman would attach more importance to the beneficial ownership of a fund, to the power to spend it for one's own purposes, than to the legal ownership of it. He would say that a fund which the husband can spend about as he likes is the husband's income. Should the Sixteenth Amendment be interpreted in the light of the meaning attributed to "income" by the man in the street? In Eisner v. Macomber, which held unconstitutional a provision of the Revenue Act of 1916 specifically taxing stock dividends as income, the minority thought so. In his dissenting opinion, Mr. Justice Brandeis said:

"In terse, comprehensive language befitting the Constitution, they [the people of the United States] empowered Congress 'to lay and collect taxes on incomes, from whatever source derived.' They intended to include thereby everything which, by reasonable understanding, can fairly be regarded as income."72

United States v. Robbins is explained if the word "income" as used in the Sixteenth Amendment is to be given this broad, popular meaning. Income, it can be said, includes not only property the legal ownership of which is acquired by the taxpayer during the tax period, but also property, the beneficial ownership of which is thus acquired.

Moreover, on this theory, the paradox that Congress can have a choice in the matter, can in its pleasure either tax half of the community income to the wife or tax the whole to the husband, disappears. At one and the same time community income is, under the Sixteenth Amendment, wholly the income of the husband and half

71 (1926) - U. S. -, 70 L. Ed., Adv. Ops. 183, 46 Sup. Ct. Rep. 148.

72 Eisner v. Macomber, 252 U. S. 189, 237. Italics added. 
the income of the wife. Congress is not limited to taxing only what falls within the popular meaning of "income"; if so minded, it may tax as income only that which falls within the stricter, legal meaning of the word.

Support for this proposition also is to be found in the dissenting opinions in Eisner v. Macomber. In the earlier case of Towne v. Eisner, ${ }^{73}$ the Supreme Court had held, Mr. Justice Holmes writing the opinion, that stock dividends were not income within the general clause of the Revenue Act of 1913 taxing "the net income of every individual." In his dissent in Eisner v. Macomber, Mr. Justice Holmes took the position that notwithstanding Towne v. Eisner Congress could, by doing so specifically, tax stock dividends as income. He said:

"I think Towne v. Eisner, 245 U. S. 418, was right in its reasoning and result, and that on sound principles the stock dividend was not income. But it was clearly intimated in that case that the construction of the statute then before the court might be different from that of the Constitution. 245 U. S. 425. I think that the word 'incomes' in the Sixteenth Amendment should be read in a 'sense most obvious to the common understanding at the time of its adoption.' . . . For it was for public adoption that it was proposed ... The known purpose of this amendment was to get rid of nice questions as to what might be direct taxes, and I cannot doubt that most people not lawyers would suppose when they voted for it that they put a question like the present to rest. I am of opinion that the Amendment justifies the tax. .."74

\section{The Husband Not "Beneficial Owner" of Community Income}

There remains, however, anotber objection to the theory that community income is wholly the income of the husband because he may spend it about as he likes. Even if the Supreme Court accepts, so far as community property is concerned, the argument that the

73 (1918) 245 U. S. 418, 62 L. Ed. 372, 38 Sup. Ct. Rep. 158.

74 252 U. S. 189,219 . In Towne v. Eisner, 245 U. S. 418, 425, Mr. Justice Holmes had said: ". . . it is not necessarily true that income means the same thing in the Constitution and the Act. A word is not a crystal, transparent and unchanged, it is the skin of a living thought and may vary greatly in color and content according to circumstances and the time in which it is used."

Cf. Mr. Justice Pitney's reference in Eisner v. Macomber to the earlier case. Speaking for the majority, he said:

"We adhere to the view then expressed, and might rest the present case there; not because that case in terms decided the constitutional question, for it did not; but because the conclusion there reached as to the essential nature of a stock dividend necessarily prevents its being regarded as income in any true sense." (252 U. S. 189, 205.) 
word "income" as used in the Sixteenth Amendment is capable of a popular interpretation-an argument which the majority refused to accept in the second Stock Dividend case-it does not necessarily follow that community income is taxable wholly to the husband. Notwithstanding his possession of power of disposition over community property, it is extremely doubtful whether he can be said to be the beneficial owner of the whole of community income.

"It is a misconception," said Mr. Justice White in Warburton v. White, ${ }^{75}$ "to suppose that because power was vested in the husband to dispose of the community property acquired during marriage as if it were his own, therefore by law the community property belonged solely to the husband." "The management, control, and power of sale of such property .... [was] vested in him, not because he was the exclusive owner, but because by law he was created the agent of the community."?

If the husband's powers are conferred upon him as agent of the community, can it be said that they constitute him the beneficial owner of the funds which comprise the community income? The passage quoted from Warburton v. White was dictum, unnecessary to the decision. But in the case of Arnett v. Reade ${ }^{77}$ this dictum was adhered to and converted into authoritative decision.

Arnett v. Reade, decided in 1911, came before the Supreme Court on appeal from the Supreme Court of the Territory of New Mexico. The latter court, adopting the reasoning of the Supreme Court of California in Spreckels v. Spreckels, ${ }^{78}$ had construed a territorial statute of 1901, requiring the wife's joinder in conveyances by the husband of community real estate, to be inapplicable to property acquired before its enactment. This construction the Supreme Court held to be erroneous and the judgment was reversed. In the opinion of the court $\mathrm{Mr}$. Justice Holmes states that the Supreme Court of the Territory put its decision "upon the notion that during the joint lives the husband was in substance the owner, the wife having a mere expectancy, and that the old saying was true that community is a partnership which begins only at its end."'79 This notion he finds to be inconsistent with the earlier territorial statutes; moreover

"The statement also directly contradicts the conception of the community system expressed in Warburton $v$. White $176 \mathrm{U}$. S.

75176 U. S. 484, 497.

76176 U. S. 484, 494.

77 (1911) 220 U. S. 311, 55 L. Ed. 477, 31 Sup. Ct. Rep. 425.

${ }^{78}$ See n. 68, supra.

79220 U. S. 311, 318-319. 
484,494 , that the control was given to the husband, 'not because he was the exclusive owner, but because by law he was created the agent of the community.' And notwithstanding the citation in Garrozi v. Dastas, 204 U. S. 64, of some of the passages and dicta from authors and cases most relied upon by the court below, we think it plain that there was no intent in that decision to deny or qualify the expression quoted from Warburton $v$. White. See Garrozi v. Dastas, 204 U. S. 78. Los bienes que han marido y muger que son de ambos por medio. Novisima Recopilacion, Book 10, Title 4, Lav 4.

"It is not necessary to go very deeply into the precise nature of the wife's interest during marriage. The discussion has fed the flame of juridical controversy for many years. The notion that the husband is the true owner is said to represent the tendency of the French customs. 2 Brissaud, Hist. du Droit Franç. 1699, n. 1. The notion may have been helped by the subjection of the woman to marital power; 6 Laferrière, Hist. du Droit Franç. 365 ; Schmidt, Civil Law of Spain and Mexico, Arts. 40,51 ; and in this country by confusion between the practical effect of the husband's power and its legal ground, if not by mistranslation of ambiguous words like dominio. See United States $v$. Castillero, 2 Black, 1, 227. However this may be, it is very plain that the wife has a greater interest than the mere possibility of an expectant heir. For it is conceded by the court below and everywhere, we believe, that in one way or another she has a remedy for an alienation made in fraud of her by her husband. Novisima Recopilacion, Book 10, Title 4, Law 5; Schmidt, Civil Law of Spain and Mexico, Art. 51; Garrozi v. Dastas, 204 U. S. 64, 78. We should require more than a reference to Randall $v$. Krieger, 23 Wall. 137, as to the power of the legislature over an inchoate right of dower to make us believe that a law could put an end to her interest without compensation consistently with the Constitution of the United States. But whether it could or not, it has not tried to destroy it, but, on the contrary, to protect it. And as she was protected against fraud already, we can conceive no reason why the legislature could not make that protection more effectual by requiring her concurrence in her husband's deed of the land." 80

It: should be noted that in both Warburton v. White and Arnett v. Reade the 'statutes which were unsuccessfully claimed to constitute the husband absolute owner of community property vested in

80 220 U. S. 311, 319-320. It is to be noted that the decision in Arnett v. Reade is not inconsistent with the case of Warburton $v$. White, supra, $n$. 64 . It does not show that the Supreme Court will determine for itself, disregarding the decisions of a state court, who owns community property. New Mexico was at this time a territory; in reversing the decision of its highest court, the Supreme Court was exercising the power of unlimited review which the highest court in a state exercises with respect to decisions by in. ferior or intermediate appellate tribunals. 
him "the like absolute power of disposition" over community property that he had over his own separate property. In Arnett v. Reade the subsequent statute, whose applicability to prior-acquired community property was involved, curtailed this absolute power of disposition. Sinular and greater limitations on the husband's power now exist in each of the community-property states. In Arnett v. Reade Mr. Justice Holnes considered it erroneous to deduce from the husband's unlimited powers "the notion that during the joint lives the husband was in substance the owner." In none of the community-property states is the husband now as much "in substance" the owner of community property as he was under the New Mexico law there involved. But, as Mr. Justice Holmes pointed out, attempts to deduce ownership from power of disposition are erroneous; the notion that the husband is the true owner has been helped "in this country by confusion between the practical effect of the husband's power and its legal ground." The legal ground of the power is that by law the husband is constituted the managing agent of the marital partnership.

Attorney General Stone, in the opinion rendered to the Secretary of the Treasury on October 9, 1924, said:

"The confusion in the decisions of the California courts has undoubtedly arisen from the fact that the courts have been attempting, in their opinions, to apply the terminology of the common law to community property, which embodies a legal concept wholly foreign to the common law, and to which the terminology of the coninion law can not be applied with accuracy and precision."

Is not this the explanation, not only of the confusion in the decisions of the California courts, but of the difficulties that have arisen in the attempt to determine whether community income should be treated as wholly the income of the husband or as only half his income?

As the Supreme Court recognized in Warburton v. White and in Arnett v. Reade, the community system involves a partnership between husband and wife, created by statute or, more exactly, by the failure of the spouses to contract out of the community-property statutes. $^{82}$ The husband is by law made the managing agent of the partnership. The large powers of control and disposition (they are not unlinited) which are conferred upon him are not intended to

8134 Ops. A. G. 395 ; reprinted in T. D. 3670, IV-8-2032, Cum. Bul. IV-1, p. 19,24 .

82 Cf. De Nicols v. Curlier [1900] A. C. 21, 69 L. J. Ch. 109. 
be used for purposes of his own. It is in the interest of the marital partnership, not in the interest of the husband, that the law confides to the husband such large powers. To restrict unduly the powers of the managing agent of the partnership would be to prevent him from effectively managing the partnership affairs. It is expected that the husband will employ the community funds in his business. If the law were to tie him down with hard and fast rules, it would defeat its own purpose in conferring power upon him. ${ }^{83}$ To permit community funds to be invested only in such safe and sure enterprises as those in which a trustee may invest trust funds under the Anglo-American law, would prevent the community from securing an adequate return upon its funds. But the husband's "right" to spend community funds about as he likes is a legal right only. Agencies of social control other than the law are relied upon to restrain him; in actual practice the husband does not spend the community income about as he likes. The absence of legal restraint upon his powers as managing agent of the marital partnership should not be held to constitute him the beneficial owner of a fund in which the wife is recognized by the state law to have a one-half interest.

\section{Uniformity in Application of Income Tax}

If an interpretation of the Sixteenth Amendment which renders the whole of community income taxable to the husband would conduce to substantial uniformity in the application of the federal income tax throughout the forty-eight states, such an interpretation would be the best possible one. Geographical uniformity in federal taxation is not only desirable; it is expressly required by the federal

83 This was recognized by the Supreme . Court in Garrozi v. Dastas (1907) 204 U. S. 64, 51 L. Ed. 369, 27 Sup. Ct. Rep. 224. This case arose in Porto Rico and involved the division of community property upon divorce. The district court had found that during the marriage the husband spent $\$ 47,000$ of the community funds during several trips to Europe and that such expenditure was unreasonable to the extent of $\$ 22,000$. Upon this finding the district court concluded, as matter of law, that the $\$ 22,000$ should be treated as an existing asset of the community subject to equal division between the parties; a personal obligation to pay $\$ 11,000$ to the wife was imposed upon the husband. The Supreme Court reversed the decision, holding that the reasonableness of expenditures made by the husband as manager of the community was not a question to be passed upon by the courts.

This case, the earlier case of Warburton v. White (supra, n. 64), and the later cases of Moffitt v. Kelly (supra, n. 18) and Arnett v. Reade (supra, n. 77) were the only cases involving community property which had come hefore the Supreme Court prior to its decision of United States v. Robbins (stipra, n. 34). 
Constitution. ${ }^{84}$ But so interpreted the word "income" would not embrace things which are substantially alike in the eight communityproperty states and in the forty non-community-property states. The community income includes the earnings of the wife as well as those of the husband. In none of the non-community-property states are the earnings of the wife taxable to the husband; the old commonlaw rule which made them his absolute property has long been universally abandoned. In some of the community-property states the income from the separate property of the wife falls into the community income $;^{85}$ in none of the other states is such income taxable to the husband. And these elements of the community income cumulate; income from invested past earnings of the wife, for example, is community income. The rights of the wife in community property, on the other hand, are real. The husband can not give it away without her consent; he can not encumber or convey community real property unless she joins. And on dissolution of the community by divorce the wife is entitled to one-half of the community property. Both husband and wife would seem to have just grounds upon which to complain that an interpretation of the Sixteenth Amendment which renders the whole of the community income taxable to the husband discriminates against them in favor of spouses residing in the non-community states. Not only does community income include funds which are not taxed as the income of the husband in the non-community states; at the very least, the rights of the husband in community income are far less, and those of the wife far greater, than the respective rights of husband and wife in non-community states in the funds which are there taxed to the husband.86 Taxing the community income wholly to the

81 U. S. Const., Art. 1, § 8, cl. 1. See Knowlton v. Moore (1900) 178 U. S. 41, 44 L. Ed. 969, 20 Sup. Ct. Rep. 747. The constitutional provision does not apply to direct taxes; but the theory of the Supreme Court seems to be that taxes on income levied under the Sixteenth Amendment are indirect taxes. See Brushaber v. Union Pacific R. Co. (1916) 240 U. S. 1, 60 L. Ed. 493, 36 Sup. Ct. Rep. 236. Moreover, the Fifth Amendment would probably be held to require that taxes not apportioned among the states be geographically uniform.

85 See n. 6, supra.

86 These assertions can be made even with respect to community property acquired under the laws of California as they existed before 1917. (E. g., the Treasury has ruled that in California the earnings of the wife are returnable by the husband. O. D. 1128, 49-21-1964, Cum. Bul. No. 5, p. 199.) If ownership recognized by state courts is to be rejected as the sole test of income-tax liability, the label attached by the California courts to the interest of the wife no longer furnishes a justification for treating such community property as not in the same category with communuity property in the other states. The husband is no more the beneficial owner of the whole of community property in California than he is in the other com- 
husband results, by reason of the graduated surtax, in an undue diminution of the fund to the prejudice of both husband and wife. The wife suffers as well as the husband because, though the tax be collected from the husband, community funds will be used to pay it.

A. more exact uniformity in the application of the income tax throughout the forty-eight states might be obtained in other ways.

A. marital community is, according to the orthodox conception, a partnership. Ordinary partners are permitted to divide the partnership income and to report their respective shares in separate returns even though those shares have not been distributed to them. Why should not marital partners be conceded a similar right?

A. trustee, we have seen, when required to pay the tax upon the income of the trust property, is permitted to file separate returns, one for his own income, the other for the trust income. ${ }^{87}$ If the community-property system must be forced into some common-law concept for purposes of federal income taxation, would not substantial uniformity be secured by treating husbands in communityproperty states as owners of one-half, and as trustees for their wives of the other half, of the community income?

If it be considered that adoption of either of these suggestions would result in discrimination in favor of spouses in the communityproperty states and against spouses in the other states, there is another possibility which is not open to that objection. We have seen that in Burk-Waggoner Oil Association v. Hopkins the Supreme Court seems to have held that Congress, under its power to classify, may treat as an entity for income-tax purposes an association which is not recognized to be an entity for other purposes by the applicable state law. ${ }^{88}$ Could not married couples in all the states be taxed as entities? The family, it has often been said, is the economic unit; why not make it the unit for income-tax purposes? ${ }^{89}$ By so doing

munity-property states. The constitutional requirement of geographical uniformity in federal taxation would seem to require that whatever rule be adopted as to community income in the other states be also adopted as to community income in California.

87 See p. 366, supra.

88 See pp. 368-371, supra.

89 It will be recalled that the real grievance of a husband and wife who are denied the right to file separate returns each for one-half of the community income is that a single return results in a higher aggregate tax payable "by the community".

It is interesting to note that under each of the income tax laws husbands and wives in any state may if they choose, but need not, file a single joint return. See, e. g., Revenue Act of 1924, § 223 (b); Reg. 65, Art. 401. This privilege is sometimes a valuable one; where one of the spouses has sustained deductible losses in excess of his gross income this excess may be deducted, in a joint return, from the income of the other spouse. 
an exact uniformity in the application of the income-tax throughout the forty-eight states could be obtained. Injustice would be done neither to husband and wife in the eight community-property states nor to husband and wife in the forty other states.

In the opinion in United States v. Robbins, Mr. Justice Holmes first examined the question whether Congress could tax the whole of community income to the husband, whether, within the meaning of the Sixteenth Amendment, the whole community income is "income" of the husband. His conclusion that Congress has a choice in the matter, that in its pleasure Congress may either tax each spouse for his or her interest in the community income or tax the husband for the whole, required that he then ask which alternative Congress had chosen in the Revenue Act of 1918. To this problem of statutory interpretation we must now turn. If, in cases arising under the Revenue Act of 1926, the Supreme Court adheres to its position that it is constitutionally permissible for Congress to tax the whole of community income to the husband, it will then be called upon to determine whether or not Congress intended that the Act of 1926 should so tax it.

\section{THE PROBLEM OF STATUTORY CONSTRUCTION}

\section{The Revenue Act of I9I8-The Robbins Case}

We may safely assume that when Congress enacted the Revenue Act of 1918 it was not aware that it had a choice in the matter, that it could either tax earh spouse for his or her interest in the community income or tax the husband for the whole. The statute levied a tax on the "net income of every individual". The problem of the court in United States v. Robbins ${ }^{90}$ was not so much to ascertain the intent of Congress as to determine the objective meaning of the words which Congress used.

If the ground upon which the court held that community income could constitutionally be taxed to the husband was that the Sixteenth Amendment was "intended to include .... everything which, by reasonable understanding, can fairly be regarded as income,"91 it is worthy of note that in holding the general terms of the Act of 1918 to embody the looser, popular conception of income Mr. Justice Holmes departed from the principle of statutory interpretation upon which he acted in the Stock Dividend cases. In the first

90 Supra, n. 34.

91 Per Brandeis, J., disseuting, in Eisner v. Macomber, supra, n. 72. 
of these cases, Towne v. Eisner, ${ }^{92}$ the court held stock dividends not to be "income" within the general terms of the Act of 1913; in the second case, Eisner v. Macomber, ${ }^{93}$ the dissenting judges, although of opinion that the provision in a later act specifically taxing stock dividends as income should be upheld, asserted that Towne v. Eisner had been correctly decided. In other words, the dissenting justices (whose views on the constitutional question seem to have been adopted by the court in United States v. Robbins) ${ }^{94}$ held that in the earlier case, in construing a statute which merely taxed "income" in general terms, the court had properly attributed to Congress an intention to adopt the stricter, legal conception of "income" rather than the looser, popular one. If, in the Robbins case, the court had adhered to this principle-had preferred the stricter, legal conception of income to the looser, popular one-it would have construed the general terms of the Act of 1918 to tax community income half to the husband and half to the wife.

The opinion in the Robbins case makes no reference to the language of the statute. ${ }^{95}$ After deciding that because the husband alone has the disposition of the fund Congress could tax him for the whole of the community income, even though it could, if so minded, tax the wife for her interest therein, Mr. Justice Holmes states that "the same and further considerations lead to the conclusion that it was intended to tax him for the whole." It is rather hard to understand how the same considerations which had led to the conclusion that Congress could, under the Constitution, exercise a choice in the matter, can furnish any indication as to what choice Congress did in fact make.

The "further considerations" to which reference is made are thus stated:

"For not only should he who has all the power bear the burden, and not only is the husband the most obvious target for the shaft, but the fund taxed, while liable to be taken for his debts, is not liable to be taken for the wife's, Civil Code, $\S 167$, so that the remedy for her failure to pay might be hard to find."

It is perhaps no objection to say that these considerations are relevant, not to the question which alternative Congress chose, but to the wisdom and policy of choosing one way rather than the other.

92 Supra, n. 73.

92 Supra, n. 72.

94 See pp. 441-442, supra.

95 The portion of the opinion here discussed is set forth in $n .44$, supra.

9c 46 Sup. Ct. Rep. 148, 149. 
More important is a doubt whether they do show the wisdom and policy of taxing the whole of community income as income of the husband. We have seen that community income includes funds not taxed as the income of the husband in the non-community states and that the rights of the husband in the community income are less, and those of the wife greater, than the respective rights of the spouses in non-community states in the fund there taxed as the income of the husband. The real question in United States v. Robbins was not, as Mr. Justice Holmes seems to assume, whether the burden of the tax should be borne by the husband or borne by the wife. The wife suffers as much as the husband if community income is taxed on the basis of a single return. From whichever spouse the tax is collected, community funds will be used to pay it; what both spouses object to is a tax computed on the basis of a single return, which subjects community income to the higher brackets of the graduated surtax, on the theory that it is the income not of two persons, but of one. To say that the husband, having the power, should bear the burden, and that it would be more convenient to collect the tax from the husband, may show the wisdom and policy of collecting the tax from the husband; it does not show the wisdom and policy of computing it on the basis of a single return. This distinction has been observed by Congress in the case of trustees, who are at law, as distinguished from in equity, the sole owners of the funds which comprise the trust income. We have seen that husband and wife would not object if the husband were taxed in the way in which a trustee is taxed when he is required to pay the taxes on the trust income. ${ }^{97}$ And yet Mr. Justice Holmes, overlooking this distinction, says:

"The reasons for holding him [the husband] are at least as great as those for holding trustees in the cases where they are liable under the law. §219. See Regulations 65, Art. 341."98

This reference to the income of a trust estate is hard to understand for an additional reason. The sentence quoted itself shows that Congress has been careful to specify in the statute the cases in which the tax is to be collected from trustees rather than from cestuis que trust. How, then, as a matter of statutory construction, can it be said that the reasons for holding the husband are at least as great as those for holding trustees?

What of the rule that a case is to be so decided and a statute so

97 See p. 366 , supra.

9846 Sup. Ct Rep. 148, 149. 
interpreted as to avoid raising a doubtful constitutional question, if it is possible so to do? In the first place, United States v. Robbins could have been decided on the ground that under the California law the wife has no interest in community income derived from community property acquired before 1917. Upon this point the court seems to have entertained little doubt. Such a decision would have raised no doubtful constitutional question and would not have affected tax-payers in the other seven community-property states; an unprejudiced day in court could have been afforded them in the future. But the decision rendered proceeds upon the assumption that in California, as in the other states, the wife has an interest in the community income which Congress could tax if so minded.9 Upon that assumption should not the statute have been so interpreted as to avoid.raising the constitutional question whether Congress could nevertheless tax the husband for the whole? Should it not have been held that a statute which merely levies a tax on the "net income of every individual" was intended by Congress to tax onehalf of the community income to the wife, in states in which she has such an interest therein that an income tax with respect to it is authorized by the Sixteenth Amendment? The contrary result reached by the court, raising as it does a doubtful constitutional question, seems hardly justified by the considerations adduced in the opinion.

\section{The Future}

The Revenue Act of 1926 is the only statute whose construction directly concerns husbands and wives in the community-property states other than California. In the past they have been permitted to file separate returns, each for one-half of the community income; we have seen that the statute of repose enacted as Section 1212 of the Revenue Act of 1926 prevents the Treasury from reopening these returns, refunding to the wife the tax paid by her, and collecting from the husband an additional tax greater in amount because of the graduated surtax than the sum refunded to the wife. ${ }^{100}$

Flusbands and wives in California, on the other hand, may be interested in the construction of each of the Revenue Acts. The state courts have not yet decided whether or not the 1917 or 1923 amendments to the California Civil Code, ${ }^{101}$ restricting the powers of the husband over community property and enlarging those of

99 See p. 362 , supra; p. 365 ff., supra.

100 See p. 362 , supra.

101 See n. 22 and $n$. 38 , supra. 
the wife, have constituted the wife co-proprietor with her husband of community property acquired since their enactment. That the amendment of 1917 alone has had that effect was held by the Federal District Court in Blum v. Wardell. If this be so, there exists in California, in addition to community income of the type which was involved in United States v. Robbins (in which the wife has a mere expectancy), a type of community income in which the wife has an interest identical with that of a wife in the other community-property states. If the Supreme Court can be persuaded that the Revenue Acts were intended to tax the wife for her interest in the con1munity income, California husbands who have been compelled to pay the tax upon the whole of community income of this type will be entitled to a refund of the difference between the amount of the tax paid (a tax computed upon the basis of a single return) and the $\operatorname{tax}$ due on the basis of separate, divided returns. Such refunds, if otherwise proper, are not precluded by the statute of repose enacted as Section 1212 of the Revenue Act of 1926, which applies only to community income "returned by the spouse to whom the incone belonged by the state law applicable to such marital community for such period."102 If community income half of which belongs by the state law to the wife does exist in California, a refusal to allow such refunds would sanction a discrimination against California husbands and wives. For if the Revenue Acts, properly construed, tax to the husband the whole of community income half of which belongs by the state law to the wife, then in spite of the constitutional requirement of geographical uniformity in federal taxation, Section 1212 waives the right of the Government to collect in the other community-property states a tax which has been collected in California.

With respect to taxes on such community income collected under the Revenue Act of 1918, California taxpayers would be entitled to refunds only if they could persuade the Supreme Court to disavow the construction placed upon that act in United States v. Robbins. That case involved only community property which had been acquired under the laws of California as they existed prior to 1917, i. e., comnunity property in which the wife has a mere expectancy; the construction placed upon the Revenue Act of 1918 could be disavowed without overruling the decision. With respect to taxes collected under the Revenue Act of 1921 and that of 1924, on the other hand, to entitle California taxpayers to such refunds it would 
not be necessary for them to attack the reasoning of the court in the Robbins case. The problem of statutory construction presented by each of these acts is quite different from the problem as to the construction of the Act of 1918 with which the court was concerned in that case.

The Revenue Acts of 1921 and 1924 each repeat the general provision contained in the Act of 1918, levying a tax on the "net income of every individual." So far as community income is concerned, these words did not receive judicial construction until United States v. Robbins was decided in January, 1926. But, prior to the enactment of either the Act of 1921 or that of 1924, the Treasury, on the advice of the Attorney General, had construed the general terms of the Act of 1918 to authorize separate, divided returns of community income half of which, under the state law, belonged to the wife. The legislative history of both the 1921 and 1924 Acts shows conclusively that Congress intended to adopt this executive construction and not the as yet non-existent judicial construction. It is well settled that when, in reënacting a statute, Congress has considered and rejected amendments which would require a change in the existing executive practice adopted under the earlier act, Congress is deemed to have indicated a purpose to authorize by the new act a continuance of that executive practice. ${ }^{103}$ Such amendments were considered and rejected by Congress both in 1921 and in 1924.

On March 3, 1921, the Treasury on the advice of the Attorney General issued Treasury Decision $3138^{104}$ authorizing husband and wife each to return one-half of community income half of which, under the state law, belonged to the wife; dissatisfied with the Revenue Act of 1918 as thus construed, the Treasury recommended to Congress that the law be changed. The bill which became the Revenue Act of 1921, as sent to the Senate by the House of Representatives accordingly provided that:

"Income received by any community shall be included in the gross income of the spouse having the management and control of the community property."105

103 Provost v. United States (1926) - U. S. - - L. Ed. -46 Sup. Ct. Rep. 152, 155; United States v. G. Falk \& Bro. (1907) 204 U. S. 143, 51 L. Ed. 411, 27 Sup. Ct. Rep. 191; Fisk v. Henarie (1891) 142 U. S. 459, 35 L. Ed. 1080,12 Sup. Ct. Rep. 207.

104 Supra, n. 17. Finance. 
The Senate Finance Committee proposed that the final words be changed so as to read "of such community" property," and that there be added the words, "and shall be taxed as the income of such spouse." ${ }^{108}$ But on the floor of the Senate, opposition was encountered. The opinion of the Attorney General was referred to and it was urged that it would be unjust, discriminatory, and perhaps unconstitutional to tax to the husband income half of which belonged to the wife. ${ }^{107}$ An amendment eliminating the provision, proposed by Senator Broussard of Louisiana (a community-property state), was adopted. ${ }^{108}$ The House concurred, and the Act of 1921 as enacted contained no reference to community income.

The legislative history of the Revenue Act of 1924 is quite similar. The Treasury again proposed that the whole of community income be taxed to the husband. ${ }^{109}$ At the hearings held by the House Committee on Ways and Means, representatives of taxpayers in the community-property states appeared, explained the communityproperty system, and urged that such a tax would be unfair and discriminatory. ${ }^{110}$ The committee eliminated the provision. The question was not referred to in either House and Congress again impliedly approved the practice, sanctioned by the Treasury since 1921, of permitting separate returns of community income half of which belongs to the wife.

\section{The Revenue Act of 1926}

The Revenue Act of 1926 presents a more difficult problem. The provision levying a tax on the "net income of every individual" is again repeated. But the Act of 1926 did not become law until February 26, 1926, and on January 4 the Supreme Court had held in United States v. Robbins that a similar provision in the Act of

100 Supra, n. 105.

10761 Cong. Rec. 5909, 5915, 5916, 5921.

10861 Cong. Rec. 5922, 7229.

109 A provision similar to that which the Senate had eliminated from the Act of 1921 was contained in the draft bill which embodied the "Mellon plan". In a letter to the Acting Chairman of the House Committee on Ways and Means, dated November 10,1923, Secretary of the Treasury Mellon said:

"6. Tax community income to the spouse having control of the income: In some states the income of the husband is a joint income of the husband and wife, and each, therefore, is permitted to file a return for one-half of the income. This gives an unfair advantage to the citizens of those states over the citizens of the other states of this country, and this amendment seeks to restore the equality. It is estimated that it will increase revenue by $\$ 8,000,000 . "$

This letter is set forth in 67 Cong. Rec. 175-176.

110 Hearings before Committee on Ways and Means, House Reports, Revenue Revision 1924, pp. 194, 348, 349, 375, 478, 482. 
1918 taxed the whole of community income to the husband. Did Congress in 1926 intend the words "net income of every individual" to have the effect which we have seen that it intended those words to have in the Acts of 1921 and 1924? Or did it intend them to have the effect which the Supreme Court had held that they were intended to have when used in the Act of 1918?

In the Act of 1926, for the first time, community income is specifically referred to. But the provision in which this reference occurs, Section 1212, the "statute of repose", is directed not to the future, but to the past. It reads:

"Income for any period before January 1, 1925, of a marital community in the income of which the wife has a vested interest as distinguished from an expectancy, shall be held to be correctly returned by the spouse to whom the income belonged under the state law applicable to such marital community for such period. Any spouse who elected so to return such income shall not be entitled to any credit or refund on the ground that such income should have been returned by the other spouse."

No reference to community income was contained in the bill until representatives of the Senate and the House met in conference to adjust the differences created by Senate amendments. On October 19, 1925, Secretary of the Treasury Mellon had advised the House Committee on Ways and Means (which was then preparing the bill) that no legislation with respect to community income was called for pending the decision of United States v. Robbins. ${ }^{111}$ On February 12, 1926, after the rendition of that decision, Senator Jones of Washington (a community-property state) offered the following amendment, which was adopted by the Senate after Senator Smoot (who was in charge of the bill) had expressed his readiness to send it to the conference for consideration by the conferees.

111 See Hearings before Committee on Ways and Means, House Reports, Revenue Revision 1925, p. 9. Secretary Mellon is reported to have said:

"Community property-There exists now in several of the states a preference to their citizens by reason of the existence of the so-called community property laws, which permit the husband and wife to return separately each one-half of their joint income, usually the income of the husband. There is a serious question in my mind as to whether or not any state, which has by the Sixteenth Amendment granted to the Federal Government the right to levy income taxes, can make the graduated income tax of the Federal Government ineffective by passing a community property law. This is a question which is now before the Supreme Court of the United States, and no legislative action is called for pending a decision. Like most difficulties, this, too, would be resolved from a practical standpoint if the surtax rates were reduced to a normal figure." 
"Retroactive Regulations-Sec. 1213. The liability of any taxpayer under any internal revenue law shall be determined (unless such taxpayer otherwise consents or requests) in accordance with the Treasury decisions, opinions of the Attorney General, and regulations made by the commissioner or by the Secretary, or by the commissioner with the approval of the Secretary, in force at the time his return was made, whether such return was made before or after the enactment of this act. As used in this subdivision, the term 'return' means, in the case of a return which has been amended, the return as finally amended."112

In this amendment the House refused to concur. In the conference the managers on the part of the House agreed to recede from such refusal if the Senate managers would alter Senator Jones' amendment to make it read as Section 1212 now reads. This was agreed to ;113 and the bill, containing Section 1212, was passed by both Houses and signed by the President.

Did Congress intend to prescribe for the future the rule which, as to the past, it sanctioned in Section 1212? When it validated regulations of the Treasury, under the earlier acts, permitting husband and wife to file divided returns of community income half of which belongs to the wife, did it intend to authorize similar regulations for the future? Or did it intend to prescribe for the future regulations requiring the husband to return the whole of community income-did it intend to let bygones be bygones but to start afresh?

The answer seems to be that the conferees, at least, thought that the effect of the decision of the Supreme Court in the Robbins case was to require that the rule as to the future be different from the rule sanctioned by Section 1212 as to the past. If this be to intend that the statute prescribe a different rule, they seem to have so intended. The decision of the Supreme Court was misapprehended. The conferees seem to have understood it to mean that Congress has, under the Constitution, no choice in the matter. We have seen that the decision does concede a choice to Congress. It may either tax each spouse for his or her interest in the community income, or tax the husband for the whole. Not realizing this, the conferees thought, mistakenly, that the general words of the act taxing the "net income of every individual" necessarily embodied the only course open to Congress to adopt; necessarily taxed the whole of community income to the husband.

11267 Cong. Rec. 3613.

113 See the conference report, set forth in 67 Cong. Rec. 4089, at 4099. 
There had been other court decisions, with respect to matters other than community income, overthrowing regulations made by the Treasury under the earlier acts. With respect to each of these decisions, a separate section embodying a statute of repose was inserted in the bill. ${ }^{114}$ In reporting the conference bill to the House, Representative Green of Iowa (one of the conference managers) explained these retroactive provisions, saying:

"There were four decisions of various courts-the Supreme Court, the Court of Claims, the Board of Tax Appeals-which would have necessitated a complete change of the regulations of the Treasury Department and going back for five or six years on some of the most complicated matters ever submitted, unless we put in this bill a retroactive provision closing up those cases on the basis of the settlement by the taxpayer and in accordance with the rules under which the Treasury Department had been acting-rules and regulations which the House itself had practically sanctioned, because it attempted to make no change in them, believed them to be valid, to be enforcible, and on the whole believed them to be the best ones that could be enacted. I refer now to the community property decision of the Supreme Court, the installment-sales decision on the part of the Board of Tax Appeals, the decision of the Supreme Court with reference to the year when taxes should be credited in determining invested capital, and the decision of the Court of Claims with reference to the force and effect of the statute of limitations."'115

If the conferees believed, as the House conference manager says that they did believe, that Congress thought the regulations which court decisions had held to be erroneous under earlier acts to be "the best ones that could be enacted," we should expect that provisions specifically authorizing such regulations for the future would have been inserted in the Act of 1926 by the conferees. Provided, of course, that they believed that Congress could constitutionally authorize such regulations for the future. Such provisions were inserted in the act. This is shown, for example, by Section 1208, the "statute of repose" with respect to installment sales:

"The provisions of subdivision (d) of section 212 shall be retroactively applied in computing income under the provisions of the Revenue Act of 1916, the Revenue Act of 1917, the Revenue Act of 1918, the Revenue Act of 1921, or the Revenue Act of 1924, or any of such acts as amended ...." 
With respect to community income, however, no such provision was inserted in the act. This is explained if the conferees mistakenly believed that United States v. Robbins had left Congress no choice in the matter, if they did not grasp the paradox that within the Sixteenth Amendment community income half of which under state law belongs to the wife is at one and the same time wholly the "income" of the husband and half the "income" of the wife.

A colloquy which took place on the floor of the House immediately after Representative Green, the House conference manager, in reporting the conference bill to the House, had made the statement hereinbefore quoted, is further evidence that the conferees thought that the effect of the decision of the Supreme Court in the Robbins case was to require that the rule as to the future be different from the rule sanctioned by Section 1212 as to the past. Representative Barbour of California had asked for more specific information as to the effect of Section 1212:

Mr. Green: "The effect of the provision with reference to community property is simply this, that we begin under new rules required by the Supreme Court decision for the year 1925."

Mr. Barbour: "That is in the Robbins case?"

Mr. Green: "Yes, and that the old rules and regulations, the old settlements, shall remain in force prior to that time."116

The conferees, then, mistakenly thought that the general words of the Act of 1926 taxing the "net income of every individual" necessarily embodied what they thought, also mistakenly, to be the only course open to Congress-that is to say, necessarily taxed the whole of community income to the husband. If such a state of mind be equivalent to an intention that the Act of 1926 tax the whole of community income to the husband, then the Act of 1926 must be deemed to have been intended to have that effect. ${ }^{117}$

* * * * * *

If the conclusions reached in this paper are correct, it follows that:

11667 Cong. Rec. 4149. Italics added. The remainder of this collogy is of importance because it shows that it was realized that Section 1212 is inapplicable to returns made by California husbands. See p. 43 , supra.

Mr. Barbour: "The taxpayers of California did not elect to pay, because they had to pay. They were compelled to pay under the rulings of the Bureau of Internal Revenue. It seems to me that that word 'elected' still leaves the matter wide open if the taxpayers of California see fit to come in, because it can not be said that they 'elected' or chose to pay as they have, because they were compelled to pay that way."

Mr. Green: "Well, I see no objection to it."

117 Is there a doctrine of dependent relative intent in the law of statutory interpretation comparable to that in the law of wills? In the leading case 
1. Community income from community property acquired under the laws of California as they existed prior to 1917 was properly returned in the past and must be returned in the future wholly by the husband.118

2. If there has existed in California, since 1917, community income half of which belongs to the wife, husbands who have paid a tax upon the whole of such income are entitled, notwithstanding Section 1212 of the Revenue Act of 1926, to a refund

(a) of taxes paid under the Revenue Act of 1924;

(b) of taxes paid under the Revenue Act of 1921;

(c) of taxes paid under the Revenue Act of 1918, if the Supreme Court can be persuaded to disavow the construction placed by it on that act in United States v. Robbins; or if that court can be persuaded to disavow the theory upon which the Robbins case was decided, viz., that community income half of which under the state law belongs to the wife may constitutionally be taxed wholly to the husband.

3. If the legislative history of the Revenue act of 1926 is deemed to indicate that Congress intended that community income in all the states should be returned wholly by the husband, it must be so returned unless the Supreme Court can be persuaded to disavow the theory upon which the Robbins case was decided, viz., that community income half of which under the state law belongs to the wife may constitutionally be taxed wholly to the husband.

Cambridge, Massachusetts.

Douglas B. Maggs.

of Camplell v. French (1797) 3 Ves. Jr. 321, Lord Loughborough held that bequests to the testator's grandnephews were not revoked by a codicil which read, in effect, " . . grandnephews having died, I revoke their bequests", when in fact the legatees were not dead.

118 See, however, n. 86, supra.

Addendum: Cal. Civ. Code, $\$ 682$, refers to the "community interest of husband and wife" as one type of "ownership of property by several persons". The statement (appearing on page 354, supra, and again in footnote 46 on page 368 , supra) that "none of the statutes contains an express declaration as to the ownership of community property" was made in view of the fact that in Spreckels v. Spreckels, supra, n. 68, the Supreme Court of California after setting forth the provisions of Civ. Code, $\S 682$, held that the husband is the absolute owner of community property and that during his lifetime the wife has a mere expectancy therein. In subsequent California cases, Roberts v. Wehmeyer, supra, n. 25, Civ. Code, $\S 682$, although relied upon by counsel, has not been referred to by the court. 